\title{
Diet of the gray fox Lycalopex griseus in an agroecosystem of southern-central Chile
}

\author{
Alfredo H. Zúñiga ${ }^{1,2,}{ }^{*}$, Víctor Fuenzalida ${ }^{3}$, and Rodolfo Sandoval ${ }^{4}$ \\ ${ }^{1}$ Laboratorio de Ecología, Universidad de Los Lagos, Alcalde Fuchslocher 1305, Casilla 933, Osorno. Provincia de Osorno, Chile. \\ Email: zundusicyon@gmail.com (AHZ). \\ ${ }^{2}$ Programa de Doctorado en ciencias mención conservación y manejo de Recursos Naturales, Universidad de Los Lagos, Puerto \\ Montt. Provincia de Llanquihue, Chile. \\ ${ }^{3}$ Consultora Ambientes del Sur, Los Renos 02080, Temuco. Provincia del Cautín, Chile. Email: victorfuenzalidaponce@gmail.com (VF). \\ ${ }^{4}$ Red de la Conservación de la Biodiversidad de Nahuelbuta, Las Araucarias 701, Contulmo. Provincia de Arauco, Chile. Email: \\ poleoverde@gmail.com (RS). \\ *Corresponding author.
}

Lycalopex griseus is a canid distributed in Chile and part of Argentina. Although its food habits have been extensively documented, data for anthropized environments are missing. Understanding the response of this species in these habitats is key, given the progressive modification of the landscape throughout its range. The study area is an agroecosystem of southern-central Chile. Scats were collected throughout the study area and analyzed in the laboratory. Food remains in scats were identified to species and quantified, considering the percentage of the various prey categories in terms of both relative frequency and relative biomass. Thirteen categories were found, with rodents dominating in terms of both relative frequency and percent biomass, followed by birds and arthropods. The presence of exotic species in the food spectrum is highlighted, represented by orders Lagomorpha and Rodentia. Plant material was found to a lesser extent. The diversity of preys evidences that Lycalopex griseus is mainly generalist in this type of habitat, as arboreal species were scarce in the diet, an expected finding considering the predominance of herbaceous vegetation in the study area. Lagomorphs were poorly represented compared to other latitudes, suggesting segregation with other species.

Lycalopex griseus es un cánido presente en Chile y parte de Argentina. Aunque sus hábitos alimentarios han sido ampliamente documentados, existen vacíos en lo que respecta al conocimiento de la ecología de esta especie en ambientes antropizados. Comprender la respuesta de esta especie a estos hábitats es relevante debido a la progresiva modificación del paisaje a lo largo de su distribución, siendo el área de estudio un agroecosistema del centro-sur de Chile. Excretas de la especie fueron colectadas a lo largo del área de estudio para su posterior análisis en laboratorio. Los restos de las excretas fueron identificados a nivel de especie y cuantificados, considerando la representación de las distintas categorías de presa tanto en términos de frecuencia relativa como de aporte de biomasa. Se registraron 13 categorías, predominando los roedores tanto en términos de frecuencia relativa como de aporte total de biomasa, seguido por aves y artrópodos. Se destaca la presencia de especies exóticas en este espectro, representados en los órdenes Lagomorpha y Rodentia. En una baja representación se encontró material vegetal. La diversidad de las presas observadas da cuenta de que éstas constituyen principalmente especies generalistas de hábitat, con una mínima representación de especies de hábitos arbóreos, considerando la predominancia de vegetación herbácea en el área de estudio. La representación de lagomorfos es menor en comparación con otras latitudes, por lo que se sugiere su segregación con otras especies.

Keywords: anthropization; lagomorphs; predation; rodents; trophic isoclines.

๑c 2018 Asociación Mexicana de Mastozoología, www.mastozoologiamexicana.org

\section{Introduction}

The South American gray fox (Lycalopex griseus) is one of the three canids present in Chile, distributed from Arica to Magellan, where it thrives in a variety of habitats (Iriarte and Jaksic 2012). The ecological aspects of this canid species have been extensively studied (Iriarte and Jaksic 2012), but information still remain scarce with regard to research in anthropized areas. The habitats of this fox species are currently under a progressive transformation across a large part of its range, resulting from the conversion of native forests into commercial crops (Echeverria et al. 2008). Thus, knowing the ecology of this species in disturbed environments is key. Any alteration of the habitat requires species to display ecological flexibility to exploit the available microhabitats (Crooks 2002), including the existing food resources, leading to various effects in the community where it thrives. The objective of this study was to docu- ment the feeding habits of $L$. griseus in an agroecosystem located to the center-south of Chile, characterized by a low biodiversity (Benton et al. 2003). In addition, this study compared the relative contribution of the prey species according to their origin (native vs. exotic), as well as in terms of the relative contribution to total biomass consumed.

\section{Materials and Methods}

The study area is located $20 \mathrm{~km}$ from Mulchén in the centersouth of Chile $\left(-37^{\circ} 49^{\prime} 42^{\prime \prime} \mathrm{S},-0.72^{\circ} 14^{\prime} 51^{\prime \prime} \mathrm{W}\right)$. This biogeographic zone has a humid climate (Di Castri and Hajek 1974) and was originally covered by deciduous forests (Gajardo 1994); today, this area has been converted into an agroecosystem mainly used to grow lupine (Lupinus spp.) and oat (Avena spp.).

During the spring (southern hemisphere) of 2016 (November/December), the study area was walked in 
search of feces through a path (forked in some areas) that runs across crops, covering a total of $4 \mathrm{~km}$. Fox scats were recognized based on gross morphology (Chame 2003) as well as on images from camera traps arranged systematically (separated by $500 \mathrm{~m}$ ) throughout the study area (Kays and Slauson 2008). These made it possible to identify individuals of the species. Scats were collected in paper bags for subsequent laboratory analysis. In the laboratory, scat samples were dried at $60^{\circ} \mathrm{C}$ and then shredded manually to obtain the remains of prey. These remains were identified based on skull morphology (Pearson 1995) and the arrangement of cuticle hairs (Day 1966), in addition to morphotypical comparisons vs. reference vouchers in the collection of Ecology and Biodiversity Laboratory at Universidad Católica de Temuco. Birds were identified based on feathers, culmen and nails. Then, the abundance of each food item relative to the total was quantified, thus obtaining the relative frequency of the different dietary groups (Rau 2000). Dietary diversity was estimated using Levins' index ( $\beta$; Levins 1968), which allows determining prey diversity from the frequency of prey consumption and the total prey categories observed. The standard deviation of this index was calculated through the Jackknife method (Jaksic and Medel 1987).

The effect of biomass on the dietary preferences of the gray fox was evaluated using the trophic isocline method (Kruuk and DeKock 1980), where the frequency of prey occurrence is graphically incorporated according to the biomass of each relative to the total consumed (Rau 2000). Trophic isoclines are arranged around percentages that allow setting the importance of a particular prey category in the diet of the predator studied (Rau 2000). In addition, we calculated the prey geometric mean based on the sum of the product of the number of individual preys by the $\log 10$ transformation of its weight (Muñoz-Pedreros et al. 2018). Rodent weight figures were obtained from MuñozPedreros and Gil (2009), as well as from the birds of Norambuena and Riquelme (2014). In the latter group, passeriform birds were considered as a consumption benchmark according to evidence from previous studies (Zúñiga et al. 2008). Arthropods and vegetation were excluded from this analysis, the former due to their poor representation relative to the total, and the latter due to the impossibility of identifying the remains collected. In addition, the prey categories observed were compared according to origin (native vs. exotic; Muñoz-Pedreros and Yáñez 2000), in terms of richness and abundance.

\section{Results}

A total of 73 scat samples were collected, finding 13 prey categories or items. These were dominated by mammals mainly rodents of the family Cricetidae (4 species) and Muridae (1 species; Table 1), with a combined relative frequency of nearly $50 \%$ (Figure 1). In addition, the remains (incisors and nails), of an Echimyidae, the coypu (Myocastor coypus), which was the prey of largest size. Lagomorphs - an exotic group at this latitude - were also included in this dietary pattern. Birds and arthropods ranked second to mammals in relative frequency of consumption by the gray fox. The trophic diversity was $\beta=7.43 \pm 1.93$ (excluding plant materials). Native species (mammals) were represented by five species ( $62.5 \%$ of total), with an abundance of 54 individuals (79.41 $\%$; non-identified rodents were excluded in both cases).

The evaluation of the effect of prey biomass on trophic isoclines revealed that rodents exceeded the $50 \%$ isocline

Table 1. Dietary consumption of Lycalopex griseus in south-central Chile, including frequency (number of preys in each item) and percentage.

\begin{tabular}{|c|c|c|}
\hline Food items & Frequency & Percentage \\
\hline \multicolumn{3}{|l|}{ MAMMALIA } \\
\hline \multicolumn{3}{|l|}{ Rodentia } \\
\hline \multicolumn{3}{|l|}{ Familia Cricetidae } \\
\hline Abrothrix longipilis & 18 & 14.51 \\
\hline Abrothrix olivaceus & 15 & 12.09 \\
\hline Irenomys tarsalis & 4 & 3.22 \\
\hline Oligoryzomys longicaudatus & 16 & 12.90 \\
\hline \multicolumn{3}{|l|}{ Familia Muridae } \\
\hline Rattus norvegicus & 4 & 3.22 \\
\hline Unidentified rodents & 3 & 2.41 \\
\hline \multicolumn{3}{|l|}{ Familia Echimyidae } \\
\hline Myocastor coypus & 1 & 0.08 \\
\hline \multicolumn{3}{|l|}{ Lagomorpha } \\
\hline \multicolumn{3}{|l|}{ Familia Leporidae } \\
\hline Lepus europaeus & 6 & 4.83 \\
\hline Oryctolagus cuniculus & 4 & 3.22 \\
\hline \multicolumn{3}{|l|}{ AVES } \\
\hline Unidentified passerines & 32 & 25.80 \\
\hline \multicolumn{3}{|l|}{ ARTHROPODA } \\
\hline \multicolumn{3}{|l|}{ INSECTA } \\
\hline \multicolumn{3}{|l|}{ Coleoptera } \\
\hline Brachysternus viridis & 2 & 1.62 \\
\hline \multicolumn{3}{|l|}{ Ortoptera } \\
\hline Cratomelus armatus & 5 & 4.03 \\
\hline Unidentified arthropods & 10 & 8.06 \\
\hline \multicolumn{3}{|l|}{ PLANT MATERIAL } \\
\hline Unidentified remains & 4 & 3.22 \\
\hline
\end{tabular}

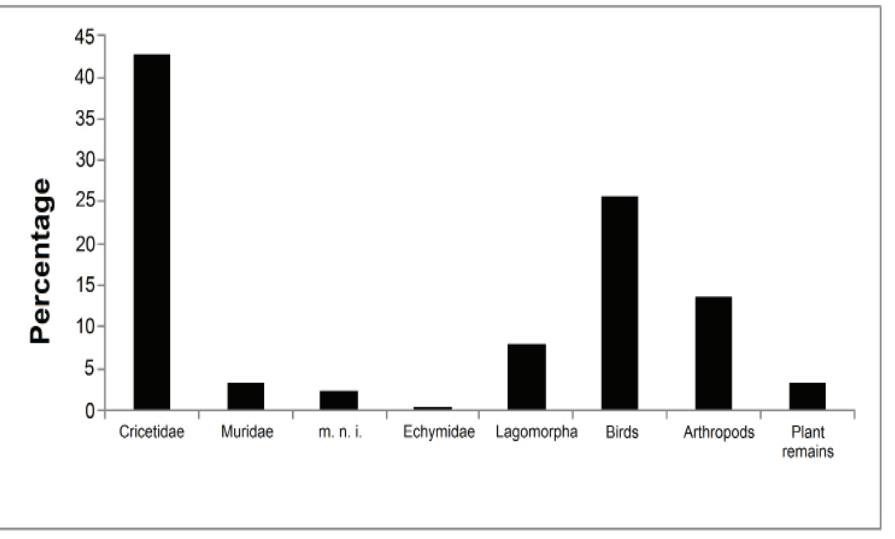

Figure 1. Percentage of prey consumption by Lycalopex griseus in south-central Chile. m. n. i.: unidentified murids. 
despite representing $40 \%$ of total biomass (Figure 2). The coypu and the hare (Lepus europaeus) were assigned to an intermediate isocline (5\%), while the rest of preys analyzed were allocated to the lowest isocline (1\%). The geometric mean for the preys analyzed was 35.35 grams.

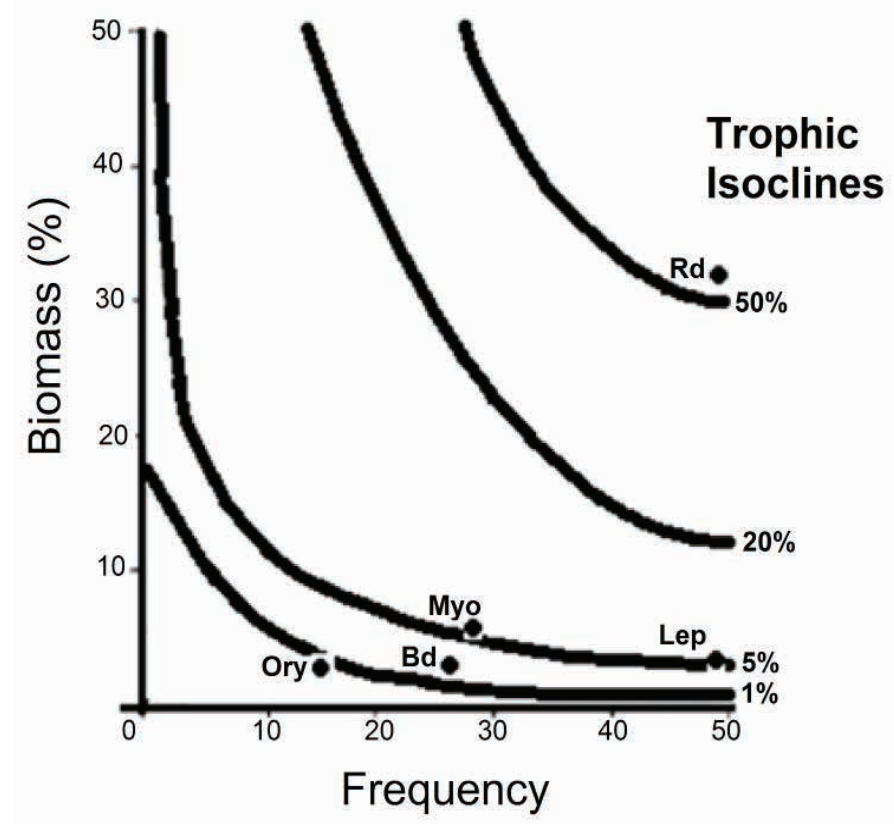

Figure 2. Trophic isoclines of preys consumed by Lycalopex griseus in the study area. Bd: Birds; Lep: Lepus europaeus, Myo: Myocastor coypus; Ory: Oryctolagus cuniculus; Rd: Rodents.

\section{Discussion}

The results obtained regarding prey diversity are consistent with those reported in other studies conducted in the center-south of Chile (Rau et al. 1995; Zúñiga et al. 2008), where small mammals - particularly rodents - constituted the core of the gray fox food spectrum. Abrothrix longipilis, A. olivaceus, Oligoryzomys longicaudatus, and, to a lesser extent, Irenomys tarsalis constituted the core of the gray fox trophic diversity in the study area. These species are characterized by their flexibility and the use of environments with little plant cover, typical of agroecosystems (MuñozPedreros and Gil 2009). The absence of species sensitive to habitat loss /or with highly restricted distributions was evidenced (Quintana 2008). The diversity of rodents observed in this study partially agrees with the records of rodents for this latitude (Muñoz-Pedreros 1992), where the sampling season coincides with their reproductive period (González and Murua 1983). This allowed recording a significant representation of local prey availability. The presence in feces of an exotic species, Rattus norvegicus, which is common in anthropized environments (Fernández and Simonetti 2013), evidences the spatial disruption that characterizes agroecosystems, where this rodent is found in optimum conditions given its ecological versatility (Jaksic et al. 2002). The geometric mean obtained is similar to the average weight of rodents, thus highlighting the importance of this group relative to the total observed. The same is interpreted from trophic isoclines: the positioning of rodents on the $50 \%$ isocline suggests that this group is a key food item within the food spectrum (Rau 2000). The presence of a single coypus specimen in the food spectrum, considering the size of this species relative to that of the gray fox $(10 \mathrm{~kg}$; Muñoz-Pedreros and Gil 2009), suggests that its consumption may have been due to scavenging rather than hunting, which assumes an incidental consumption. This is based on the fact that the gray fox and the coypu are of similar size (Iriarte and Jaksic 2012), which would make it difficult for the fox to hunt it; additionally, there are no records of this prey in the gray fox diet in areas where both coexist (Zúniga et al. 2008). The higher number of scats collected in this study vs. the figure recorded by Torés (2007) for the culpeo fox (Lycalopex culpaeus), where a significant representation of the local prey diversity was reported, suggests that the number of samples in this study was sufficient to achieve representativeness of the dietary analysis.

A noteworthy finding is the absence of marsupials such as the Monito del Monte (Dromiciops spp.), in the diet of the gray fox, which contrasts with other studies on this canid in the center-south of Chile (Zúñiga et al. 2008). This fact could be explained by the constraints of the study area to be occupied by this marsupial, due the close relationship of the monito del monte with the native forest, as well as its displacement limitations (Fonturbel et al. 2010). On the other hand, the broad range of movement of the fox across patches of native forest (Zúñiga et al. 2009) would facilitate the consumption of this prey. This suggests a small population size of this marsupial species, which deserves to be further investigated. In this way, the absence of arboreal species in the diet of the gray fox is compensated by the presence of species of terrestrial habits. However, the presence of Irenomys tarsalis in the diet of the fox shows the flexibility of this rodent in the use of microhabitats with low vegetation cover, despite its preference for forested areas (Kelt 1993), which would lead to a lower frequency of capture vs. the rest of the cricetids observed.

The low consumption of lagomorphs according to the trophic isoclines contrasts with the observations for Lycalopex culpaeus, a canid of larger size than the gray fox that has been reported in other latitudes (Rubio et al. 2013; Zúñiga and Fuenzalida 2016), where the frequency of consumption is considerably higher. This finding leads to setting two types of hypothesis: on the one hand, the assumed high abundance of lagomorpha this group is not supported, despite the success experienced as exotic species at this latitude, which has enabled it to spread rapidly across the Chilean territory (Jaksic et al. 2002). On the other hand, an interference effect by larger predators, such as the puma, in the study area, leading to a spatial overlap (Zúñiga et al. 2009), and ultimately, to competition by exploitation. Both hypotheses should be tested in further studies to investigate which ecological elements affect this canid in anthropized areas, taking into account the variations in prey availability resulting from seasonal effects and changes of land use. 
The frequency of bird consumed by L. griseus in the study area is consistent with the records from native forests in the same biogeographic zone (Zúñiga et al. 2008). However, the impossibility to identify the species consumed has restrained the estimation of the trophic spectrum of this canid (underestimation of the Levins' index; Greene and Jaksic 1983), considering the diversity of birds in this habitat (Zúñiga 2014). Nonetheless, the low contribution of birds to total prey biomass, as reflected by their inclusion in the $1 \%$ isocline, suggests that this group is a minor component of the gray fox diet, in spite of its frequency of consumption. A similar finding was observed for arthropods, i.e. the amount of arthropod biomass was negligible in relation to the total, despite their frequency of consumption. This fact is even more significant considering arthropod richness at a regional scale (Peña 1987); hence, it should be interpreted with caution.

The plant remains observed differ from what is documented in localities including native forests, where the presence of seeds of several species has been reported (Zúñiga et al. 2008; Morales-Paredes et al. 2015), suggesting a potential role of the gray fox in seed dispersal. The scarcity of plant remains may indicate a change in the vegetation pattern as habitat fragmentation continues in the study area. Given this scenario, further studies are required that consider the richness of plant species according to their interaction with the local fauna.

\section{Acknowledgments}

We thank two anonymous reviewers for their comments, which substantially improved this manuscript. María Elena Sánchez-Salazar translated the manuscript into English.

\section{Literature Cited}

Benton, T. G., J. A. Vickery, And J. D. Wilson. 2003. Farmland biodiversity: is habitat heterogeneity the key? Trends in Ecology and Evolution 18:182-188.

Chame, M. 2003. Terrestrial mammal feces: a morphometric summary and description. Memoriás do Instituto Oswaldo Cruz 98:71-94.

CROOKS, K. R. 2002. Relative sensitivities of mammalian carnivores to habitat fragmentation. Conservation Biology 16:488-502.

DAY, M. 1966. Identification of hair and feather remains in the gut and feces of stoats and weasels. Journal of Zoology 148:201-207.

Di Castri, F., and E. Hajek. 1976. Bioclimatología de Chile. Ediciones Universidad Católica de Chile, Santiago, Chile.

Echeverría, C., D. Coomes, J. Salas, J. M. Rey-Benayas, A. Lara, and A. NEwTON. 2008. Rapid fragmentation and deforestation of Chilean temperate forest. Biological Conservation 130:481-494.

Fernández, I. C., and J. A. Simonetti. 2013. Small mammal assemblage in fragmented shrublands of urban areas of Central Chile. Urban Ecosystems 16:377-387.

Fontúrbel, F. E., E. A. Silla-Rodriguez, N. H. CÁrdenas, and J. E. Jiménez. 2010. Spatial ecology of monito del monte (Dromiciops gliroides) in a fragmented landscape of southern Chile. Mammalian Biology 75:1-9.
GAJARDO, R. 1994. La vegetación natural de Chile, clasificación y distribución geográfica. Editorial Universitaria. Santiago, Chile.

GonzÁlez, L., AND R. MurúA. 1983. Características del periodo reproductivo de tres especies de roedores cricétidos del bosque higrófilo templado. Anales del Museo de Historia Natural (Chile) 16:87-99.

Greene, H. W., AND F. M. JaKsIC. 1983. Food-niche relationships among sympatric predators: effects of level of prey identification. Oikos 40: 151-154.

IRIARTE, A., AND F. JAKSIC. 2012. Los carnívoros de Chile. Flora and Fauna/CASEB Ediciones. Santiago, Chile.

JAKSIC, F., AND R. MEDEL. 1987. El acuchillamiento de datos como método de obtención de intervalos de confianza y de prueba de hipótesis para índices ecológicos. Medio Ambiente 8:95-103.

Jaksic, F. M., A. Iriarte, J. E. Jiménez, and D. R. Martínez. 2002. Invaders without frontiers: cross-border invasions of exotic mammals. Biological Invasions 4:157-173.

KaYs, R., AND K. M. Slauson. 2008. Remote cameras. Pp. 110140, in Non invasive survey methods for carnivores (Long, R., P. Mackay, W. Zielinski, and J. Ray, eds.). Island Press, Washington, U. S. A.

KeLt, D. A. 1993. Irenomys tarsalis. Mammalian Species 447:1-3. KRUUK, H., AND L. De Kock. 1980. Food and habitat of badgers (Meles meles L.) on Monte Baldo, northern Italy. Zeitschrift fur Saugertierkunde 46:295-301.

LEVINS, R. 1968. Evolution in a changing environments. Princeton University Press, Princeton, U. S. A.

Morales-Paredes, C. C. E. Valdivia, And S. SAde. 2015. La frugivoría por cánidos nativos (Lycalopex spp.) y alóctonos (Canis lupus familiaris) reduce la germinación de semillas de litre (Lithrea caustica) en Chile Central. Bosque 36: 481-486.

Muñoz-Pedreros, A. 1992. Ecología del ensamble de micromamíferos en un agroecosistema forestal de Chile Central. Una comparación latitudinal. Revista Chilena de Historia Natural 65:417-428.

Muñoz-Pedreros, A., And J. Yánez. 2000. Mamíferos de Chile. CEA Ediciones. Valdivia, Chile.

Muñoz-Pedreros, A., AND C. Gil. 2009. Orden Rodentia. Pp. 93157, in Mamíferos de Chile (A. Muñoz-Pedreros, and J. Yáñez, eds.). Mamíferos de Chile. CEA Ediciones, Valdivia, Chile.

Muñoz-Pedreros, A., J. Yánez, H. V. Norambuena, And A. Zúñiga. 2018. Diet, dietary selectivity and density of South American grey fox, Lycalopex griseus, in Central Chile. Integrative Zoology 13:46-57.

Norambuena, H., and J. Riquelme. 2014. Profesor Francisco Behn Kuhn (1910-1976) biografía y catálogo de aves chilenas. CEA Ediciones, Valdivia, Chile.

Pearson, O. 1995. Annotated keys on near Nahuel Huapi National Park or Lanin National Park, Southern Argentina. Mastozoología Neotropical 2:99-148.

PENAA, L. 1987. Introducción al estudio de los insectos en Chile. Editorial Universitaria, Santiago, Chile.

Quintana, V. 2008. Diversidad de micromamíferos en la región de la Araucanía, sur de Chile. Gestión Ambiental 16:41-52.

RAu. J. 2000. Métodos de ecología trófica. Pp. 397-406, in Mamíferos de Chile (Muñoz-Pedreros, A., and J. Yáñez, eds.). CEA Ediciones. Valdivia, Chile. 
Rau, J., D. Martínez, J. Low, and M. Tillería. 1995. Depredación por zorros chilla (Pseudalopex griseus) sobre micromamíferos cursoriales, escansoriales y arborícolas en un área silvestre protegida del sur de Chile. Revista Chilena de Historia Natural 68:333-340.

Rubio, A., R. Alvarado, And C. Bonacic. 2013. Introduced European rabbit as main prey of the native carnivore culpeo fox (Lycalopex culpaeus) in disturbed ecosystems of central Chile. Neotropical Fauna and Environment 48:89-94.

Torés, N. 2007. Dieta estival del culpeo (Pseudalopex culpaeus, Molina 1782) en Nevados de Chillán, centro-sur de Chile. Memoria para optar al título de Médico Veterinario, Universidad Austral de Chile, Chile.

ZúñIGA, A. 2014. Composición de un ensamble de aves en un fragmento boscoso del sur de Chile. Gestión Ambiental 27:35-45.

ZúNIIGA, A., AND V. FuenZalidA. 2016. Dieta del zorro culpeo (Lycalopex culpaeus Molina 1782) en un área protegida del sur de Chile. Mastozoología Neotropical 23:201-205.

Zúñiga, A., A. Muñoz-Pedreros, and A. Fierro. 2008. Dieta de Lycalopex griseus (Gray, 1837) en la depresión intermedia del sur de Chile. Gayana 72:113-116.

ZúñIgA, A., A. Muñoz-Pedreros, And A. Fierro. 2009. Uso de hábitat de cuatro carnívoros terrestres en el sur de Chile. Gayana 73:200-210.

Associated editor: Monica Díaz

Submitted: November 19, 2017; Reviewed: May 14, 2018;

Accepted:March 5, 2018; Published on line:May16, 2018. 
